\title{
Susan Elaine Gray \\ I Will Fear No Evil: Ojibwa-Missionary Encounters Along the Berens River, 1875-1940.
}

Calgary: University of Calgary Press, 2006. 214 pp.

\section{Martin J. Whittles}

The dynamics and legacies of cultural change are germane to any discussion on the history of education. Does cultural contact invariably result in the insoluble collisions of world-views, or can imported ideas mingle with indigenous ones, so as to complement, rather than supplant, traditional life-ways? Are smaller, traditional societies inevitably doomed to be crushed in an avalanche of noxious institutions that originate at a distance - in the mother country, colonial metrople, or increasingly, through the crush of massmediated hegemonic messages? Does cultural change not only modify what is learned, but how?

In addressing these questions, I Will Fear No Evil challenges common assumptions that First World colonialism has been (and remains) a unidirectional, inevitable, and comprehensive juggernaut of forced assimilation. That view is replaced with Susan Gray's model of post-contact cultural blending, parsimonious social change, and the selective acceptance and incorporation of 'new ways' by Indigenous peoples. Indeed, she posits that an understanding of selective syncretism - where intersecting cultural elements become fused into emergent meanings and expressions, different from both of the original, singular traditions - offers us insight behind the webs of negotiation, arbitration, and accommodation experienced by both colonizer and colonized in frontier settings.

Set in the traditional territory of the Berens River Ojibwa (Saulteaux) on the Canadian Shield in central Manitoba over the two generations following the negotiation and implementation of Treaty Five in 1875, the present work documents a wide range of social changes in Aboriginal lives. Chronologically recording transformations in the political, economic, and social life of the community, I Will Fear No Evil opens with a comprehensive ethnography of life before and following Euro-Canadian contact. These changes, often rapid, dramatic, and tragically prime examples of revolutionary ethnocide, also 
reflected the adaptive, flexible, and discriminating choices made by the Ojibwa in their deliberate and evolving desire to avoid colonial dependency and cultural decline. Examples of life immediately following Euro-Canadian contact span the opening of traditional territory to homesteading outsiders and non-Native commercial fishers, hunters, and trappers. This population influx was followed in quick succession by the deterioration in standards of living as formerly bountiful fur, meat, and fish stocks declined through nonNative over-harvesting, and by the devastating results of wave after wave of imported epidemics. These epidemics included influenza in 1890, measles in 1893, scarlet fever in 1894, tuberculosis and scrofula in 1894, and of course, Spanish influenza in 1918. Examples of resistance and accommodation skillfully illuminated by Gray include Ojibwa challenge to successive missions - initially Methodist, later Roman Catholic - through avoidance of patron-client relationships, vigorous negotiation of the ground rules for contact, and active decision-making when they found matters of Christian faith and the rigours of church membership to be at odds with traditional teachings and lifeways.

Although very much an historian, Gray utilizes a well-worn anthropological toolkit in her pursuit of the deeper story here, including participant observation in Barens River, extensive interviewing, and the collecting of oral evidence. There is solid scholarship in these chapters. Gray asks readers to challenge conventional historic narratives and consider that the self-defined "progress towards civilization" described by enthusiastic missionaries in the field (a goal that was embraced equally wholeheartedly by the selfrighteous society they claimed to represent), was neither as complete nor as passively accepted by Aboriginal people as reported. This despite the fact that missionaries wrote home with racist and hopeful reports, including those that claimed, "The morality of the people is not sufficiently developed to merit high praise... however we hope that [Ojibwa] society is moving out of darkness into light and knowledge and that the future will bring a purer social condition" (p. 11). Instead, Gray paints a picture of remarkable cultural complexity shared among the original people of the east side of Lake Winnipeg, and challenges readers to avoid simple models of colonial vandalism and widespread cultural replacement.

So what is to be learned from what may strike some readers as revisionist history fashioned to assuage so-called White Guilt? For the Berens River Ojibwa, Gray explains, intellectual and ideological coexistence avoided the classic dualism of Christianity, recasting the missionary's messages of salvation into a complex fabric of blended belief and experience, thus skillfully avoiding an exclusivity of devotion. Thus, the other-thanhuman abilities of Thunderbirds and spirit guides, the curative and clairvoyant value of the fabled shaking tent ritual, the widespread belief in cannibalistic Windigo spirits, and the social place of medicine men and those who Gray calls 'conjurers' remained. Imported Christianity, whether from the liturgies delivered by Methodists or Roman Catholics, was embraced only inasmuch as it supplemented and enhanced the power the Ojibwa already received from their own spirit helpers. Interestingly, any Aboriginal frustration concerning these issues reported by Gray was rarely directed at the missionaries, their convictions, or their efforts; rather she illuminates what her informants often perceived to be the inelegant myopia of Christianity. Witness Percy Berens who laments, "If we don't have Thunderbirds, maybe we would never have had rain? And the whole earth would be just dried up. And then where are we going to be? Don't you know, you white 
people, don't you know enough that everything God created meant something to the people and to the beasts of the world?” (p. 152).

Examples of syncretism were also to be found in Ojibwa attitudes towards literacy and their wish for Western education — as early as 1881 — when band members boycotted church-operated schoolhouses for what they felt was inferior instruction, instead petitioning the Department of Indian Affairs to build a day school. Clearly, the Ojibwa "placed enough value on providing an education for their children to become actively involved; in this case, the value of a good education won out over loyalty to the Methodist missionary" (p. 67). As Gray explains, education was a means to an (indigenously defined) end only, and therefore a strategy to assist continued Aboriginal survival in a world constantly altered and manipulated by Euro-Canadians.

I Will Fear No Evil is a comprehensive assessment of cultural change and its effect on belief, experience, and self-awareness. Gently nuanced testimony from her informants, blended with incisive archival content and a forthright and astute interpretation by Susan Gray, combine to make for a solid resource for scholars and students seeking a fresh approach to a complex and contested topic. 
116 Historical Studies in Education/Revue d'histoire de l'éducation 